\title{
Ambient particulate air pollution from vehicles promotes lipid peroxidation and inflammatory responses in rat lung
}

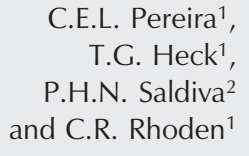

C.E.L. Pereira ${ }^{1}$, T.G. Heck ${ }^{1}$, P.H.N. Saldiva ${ }^{2}$ and C.R. Rhoden ${ }^{1}$

\author{
${ }^{1}$ Curso de Pós-graduação em Ciências Médicas e Laboratório de Estresse Oxidativo e \\ Poluição Atmosférica, Fundação Faculdade Federal de Ciências Médicas de Porto \\ Alegre, Porto Alegre, RS, Brasil \\ ${ }^{2}$ Laboratório de Poluição Atmosférica Experimental, Departamento de Patologia \\ (LIM05), Faculdade de Medicina, Universidade de São Paulo, São Paulo, SP, Brasil
}

\section{Correspondence \\ C.R. Rhoden \\ Rua Jaraguá, 370/302 \\ 90450-140 Porto Alegre, RS \\ Brasil \\ Fax: +55-51-338-810 \\ E-mail: crhoden@fffcmpa.edu.br \\ Research supported by Fundação Faculdade Federal de Ciências Médicas de Porto Alegre, Brazil. C.E.L. Pereira was supported by a fellowship from CAPES, C.R. Rhoden and P.H.N. Saldiva were supported by $\mathrm{CNPq}$.}

Publication supported by FAPESP $\ldots \ldots \ldots \ldots \ldots \ldots$

Received December 12, 2006 Accepted June 25, 2007

\begin{abstract}
Oxidative stress plays a major role in the pathogenesis of particledependent lung injury. Ambient particle levels from vehicles have not been previously shown to cause oxidative stress to the lungs. The present study was conducted to a) determine whether short-term exposure to ambient levels of particulate air pollution from vehicles elicits inflammatory responses and lipid peroxidation in rat lungs, and b) determine if intermittent short-term exposures (every 4 days) induce some degree of tolerance. Three-month-old male Wistar rats were exposed to ambient particulate matter (PM) from vehicles $(\mathrm{N}=$ 30) for 6 or 20 continuous hours, or for intermittent $(5 \mathrm{~h})$ periods during $20 \mathrm{~h}$ for 4 consecutive days or to filtered air $(\mathrm{PM}<10 \mu \mathrm{m} ; \mathrm{N}=$ 30). Rats continuously breathing polluted air for $20 \mathrm{~h}$ (P-20) showed a significant increase in the total number of leukocytes in bronchoalveolar lavage compared to control (C-20: $2.61 \times 10^{5} \pm 0.51 ; \mathrm{P}-20: 5.01$ $\left.\mathrm{x} 10^{5} \pm 0.81 ; \mathrm{P}<0.05\right)$ and in lipid peroxidation ([MDA] nmol $/ \mathrm{mg}$ protein: C-20: $0.148 \pm 0.01$; P-20: $0.226 \pm 0.02 ; \mathrm{P}<0.05)$. Shorter exposure $(6 \mathrm{~h})$ and intermittent 5 -h exposures over a period of 4 days did not cause significant changes in leukocytes. Lipid damage resulting from 20-h exposure to particulate air pollution did not cause a significant increase in lung water content. These data suggest oxidative stress as one of the mechanisms responsible for the acute adverse respiratory effects of particles, and suggest that short-term inhalation of ambient particulate air pollution from street with high automobile traffic represents a biological hazard.
\end{abstract}

Key words

- Oxidative stress

- Reactive oxygen species

Lipid peroxidation

- Particulate air pollution

- Lung inflammation

- Acute effects

\section{Introduction}

Epidemiological studies have shown that exposure to particulate matter is associated with increased cardiopulmonary morbidity and mortality (1-9), hospital admissions
$(10,11)$, and sudden death (12). However, the mechanism by which particulate matter promotes these effects is not understood. Stringer and Kobzik (13) suggested that particulate matter toxicity might be due to increased generation of reactive oxygen spe- 
cies in target cells. Gurgueira et al. (14) reported that short-term exposure to concentrated ambient particles (CAPs) leads to a significant increase in oxidant levels in the heart and lung of rats which was associated with edema in these tissues. Rhoden et al. (15) showed that previous treatment with a general antioxidant ( $\mathrm{N}$-acetylcysteine) prevented lung inflammation induced by shortterm CAP exposure.

The data cited above suggest that oxidative stress to the pulmonary parenchyma plays a major role in the pathogenesis of particle-dependent lung injury. However, it is important to note that the oxidative stress induced by particles in experimental animal studies was obtained with concentrated ambient particles or with tracheal instillation $(14,15)$. Particles in the ambient from vehicles have not been shown to cause oxidative stress to the lungs. The present study was conducted in order to address this question, with two main objectives: a) to determine whether short-term exposure (6 or 20 h) to ambient levels of urban aerosols from a street with high automobile traffic elicits oxidative damage to membrane lipids in the lung, and b) to determine if intermittent shortterm exposures ( 5 h per day) every 4 days induce some degree of tolerance.

\section{Material and Methods}

\section{Site of exposure}

Porto Alegre has a population of approximately 1.5 million inhabitants; it is the central city of an industrialized metropolitan area of 3.2 million inhabitants. The vehicle fleet was 522,555 vehicles in March 2004 (16), or about 1 vehicle for every 2.7 individuals, and an increase of $4.5 \%$ vehicles occurs every year. Vehicle traffic is the main source of air pollution in the larger cities of Brazil, being responsible for approximately $90 \%$ of carbon monoxide and particulate matter $_{10}$ emissions, with air pollution repre- senting a serious problem in many regions $(17,18)$. The total area of Porto Alegre is $496,827 \mathrm{~km}^{2}$ with $40 \%$ of the urban area being occupied by the transportation structure (16). This city presents frequent thermal inversions and defined climate seasons. Average temperature ranges from 18 to $25^{\circ} \mathrm{C}$, and average rainfall days range from 3 to 6 per month (based on 8 years of historical weather readings; climate zone http://www. climate-zone.com/climate/brazil/fahrenheit/ porto-alegre.htm).

\section{Animals}

Adult 3-month-old male Wistar rats from the Animal Facility of Fundação Faculdade Federal de Ciências Médicas de Porto Alegre were used. Animals were kept under 12$\mathrm{h}$ light-dark periods and had free access to a standard laboratory diet (Supra-lab, Alisul Alimentos S/A., São Leopoldo, RS, Brazil) and water before and during the exposure.

\section{Exposure chambers}

Exposure chambers were made of glass $(30 \times 30 \times 50 \mathrm{~cm})$ and were hermetically closed, with the exception of one entrance (connected to the outdoor environment) and one exit. A vacuum pump was connected to the exit and pumped outdoor air through the exposure chambers at a flow rate of $10 \mathrm{~L} /$ min. Inhalation chambers were located on the second floor of the building of Fundação Faculdade Federal de Ciências Médicas de Porto Alegre, located in downtown Porto Alegre at a crossroad with heavy traffic (Sarmento Leite Street and André da Rocha Street), facing an automated air pollution monitoring station of the State Environmental Agency, that provides continuous particulate matter measurements (beta monitor). One of the chambers (designated as control) was equipped with a 37-mm Teflon filter (Millipore, Carrigtwohill, Ireland) in the inlet, which prevented the admission 
of ambient particles, whereas the other received atmospheric air without the filtering system (designated as polluted). The temperature in the room and in the chamber was $22 \pm 2^{\circ} \mathrm{C}$.

\section{Experimental protocol}

Continuous short-term exposure to particulate matter. Rats were exposed to ambient particles from vehicles (polluted group) or filtered air (control group) for periods of 6 h (on August 4, 2004) or 20 h (on August 17, 2004), as described above. The animals were allowed to move freely in the cage during the exposure and both groups were exposed and tested simultaneously. Immediately after the exposure, animals were anesthetized $i p$ with $50 \mathrm{mg} / \mathrm{kg}$ pentobarbital and killed by exsanguination. The right lung of each animal from both groups was excised and quickly frozen in liquid nitrogen for lipid peroxidation evaluation and the left lung of each animal was excised and used to determine lung edema. Another group of animals was submitted to the same protocol and to bronchoalveolar lavage $24 \mathrm{~h}$ later to determine the inflammatory parameters. The protocol of bronchoalveolar lavage for the 6-h exposure was performed on two different days (July 12 and July 20, 2004), whereas the 20-h exposure was performed on September 17, 2004. The ambient levels of particulate matter from vehicles on the days of exposure varied from 22 to $224.7 \mu \mathrm{g} / \mathrm{m}^{3}$ (Table 1).

The times of exposure were based on experimental studies in which animals were exposed to concentrated ambient particles for 3 and $5 \mathrm{~h}$, with an increase in oxidant levels being detected in the lungs and heart $(14,19)$.

Intermittent short-term exposure to ambient particulate matter from vehicles. Rats were exposed to consecutive particulate matter inhalations (polluted group) or filtered air (control group) during periods of 20 h (5 h/day, 4 consecutive days, from September 6 to 9, 2004), as described above. The ambient particulate matter concentrations on the days of exposure are listed in Table 1 . The animals were awake and movement was unrestricted during exposure. Both groups were exposed and tested simultaneously. Immediately after the last exposure the animals were submitted to the same procedure as described above for the collection of lung samples for lipid peroxidation and edema determination.

\section{Tissue preparation}

The lungs were excised, washed in saline solution and quickly frozen in liquid nitrogen. For the determination of thiobarbituric acid reactive substances (TBARS), tissue samples were homogenized in 5 volumes of $120 \mathrm{mM} \mathrm{KCl}$ and $30 \mathrm{mM}$ sodium phosphate buffer, $\mathrm{pH} 7.4$, containing $0.5 \mathrm{mM}$ phenylmethanesulfonyl fluoride as a protease inhibitor, at $0-4^{\circ} \mathrm{C}$. The suspensions were centrifuged at $600 \mathrm{~g}$ for $10 \mathrm{~min}$ at $0-4^{\circ} \mathrm{C}$ to remove nuclei and cell debris. The pellets were discarded and the supernatant solutions were used as homogenates.

\section{Determination of thiobarbituric acid reactive substances - lipid peroxidation}

Lung homogenates were precipitated with $10 \%$ TCA, centrifuged, and incubated with thiobarbituric acid (Sigma, St. Louis, MO, USA) for $15 \mathrm{~min}$ at $100^{\circ} \mathrm{C}$ and TBARS were

Table 1. Concentration of particulate matter $\left(\mathrm{PM}_{10}\right)$ in the air to which rats were exposed.

\begin{tabular}{llc}
\hline Protocol & Date & $\mathrm{PM}_{10}\left(\mu \mathrm{g} / \mathrm{m}^{3}\right)$ \\
\hline Continuous short-term exposure $(6 \mathrm{~h})$ & July 12, 2004 & 34.0 \\
Continuous short-term exposure $(6 \mathrm{~h})$ & July 20, 2004 & 22.0 \\
Continuous short-term exposure $(6 \mathrm{~h})$ & August 4, 2004 & 224.7 \\
Continuous short-term exposure $(20 \mathrm{~h})$ & August 17, 2004 & 138.6 \\
Continuous short-term exposure $(20 \mathrm{~h})$ & September 17, 2004 & 112.4 \\
Intermittent short-term exposure $(4 \mathrm{~h} /$ day) & September 6-9, 2004 & 99.2 \\
\hline
\end{tabular}


extracted with butanol $(1: 1 \mathrm{v} / \mathrm{v})$. After centrifugation, the absorbance of the butanol was measured at $535 \mathrm{~nm}$ (20). The amount of TBARS formed is reported as $\mathrm{nmol} / \mathrm{mg}$ protein. Malondialdehyde standards were prepared from 1,1,3,3,-tetramethoxypropane. Protein concentration in the homogenates was measured by the Bradford protein assay (21) using bovine serum albumin as standard. Measurements were carried out in a Perkin Elmer Lambda 40 spectrophotometer (Shelton, CT, USA).

\section{Lung edema}

The severity of pulmonary edema was determined by the wet/dry ratio. Lung samples (about $200 \mathrm{mg}$ ) taken from the same animals as used for TBARS determination were weighed and dried in a conventional oven $\left(\right.$ at $90^{\circ} \mathrm{C}$ ) until they reached constant weight. The results are reported as wet/dry ratios $(\mathrm{g} / \mathrm{g})$.

\section{Bronchoalveolar lavage}

Rats exposed to polluted or filtered air were anesthetized with sodium pentobarbital $(50 \mathrm{mg} / \mathrm{kg}$ body weight) $24 \mathrm{~h}$ after exposure and euthanized by exsanguination. The trachea was sectioned, a fine catheter was introduced and fixed with cotton thread, and $21 \mathrm{~mL}$ sterile saline solution was injected in three series of $7 \mathrm{~mL}$, followed by aspiration. The rate of recovery of the injected solution was approximately $80 \%$. Each aliquot represents one injected and one drawn in recovery of fluid. The recovered fluid was centrifuged at $400 \mathrm{~g}$ at $6^{\circ} \mathrm{C}$ and the supernatant from the first lavage was saved for the measurement of protein level. Total cell counts were determined after Trypan blue staining using a Neubauer chamber. Total protein levels, as a measure of vascular permeability, were determined in the supernatant of the first lavage aliquot by the Bradford protein assay (21) using a Perkin Elmer Lambda 40 spectrophotometer.

\section{Animal care}

Animals were handled humanely throughout the study to minimize their discomfort and to prevent distress. All protocols were approved by the Research Ethics Committee of Fundação Faculdade Federal de Ciências Médicas de Porto Alegre (CPA 085/03).

\section{Statistical analysis}

Data are reported as means \pm SEM. Statistical analyses were performed by the unpaired Student $t$-test using the Sigma-Stat 2.0 Software (Jandel Corporation, 19921995, San Jose, CA, USA), with the level of significance set at $5 \%$.

\section{Results}

Rats breathing ambient particulate matter from vehicles for $6 \mathrm{~h}$ did not show increased lipid peroxidation in the lungs (Figure 1A). However, when the animals were continuously exposed for $20 \mathrm{~h}$ a statistically significant increase in this parameter was detected in their lungs (Figure 1B), but not in the lungs of rats exposed intermittently to particulate matter for $20 \mathrm{~h}$ (Figure 1C).

Rats exposed to filtered air or not for $6 \mathrm{~h}$ did not show an increase in leukocytes in bronchoalveolar lavage (BAL; Figure 2A). In agreement with the results of lipid peroxidation, rats continuously exposed to vehicular pollution for $20 \mathrm{~h}$ showed a significant accumulation of leukocytes in BAL, as compared with BAL from rats exposed to filtered air (Figure 2B). However, accumulation of leukocytes in BAL was not accompanied by significant changes in total protein levels (continuous short-term $6 \mathrm{~h}$ : control $=0.96 \pm$ $0.10 v s$ polluted $=1.05 \pm 0.08 \mathrm{mg} / \mathrm{mL}, \mathrm{P}=$ 0.607 ; continuous short-term $20 \mathrm{~h}$ : control $=$ $1.34 \pm 0.14 v s$ polluted $=1.39 \pm 0.09 \mathrm{mg} / \mathrm{mL}$, 
$P=0.763$ ). Finally, the wet/dry ratio, a measurement of global tissue damage, was not changed by exposure to pollution (continuous short-term $6 \mathrm{~h}$ : control $=4.87 \pm 0.09 v \mathrm{~s}$ polluted $=4.85 \pm 0.18 \mathrm{~g} / \mathrm{g}, \mathrm{P}=0.924$; continuous short-term $20 \mathrm{~h}$ : control $=5.25 \pm$ $0.08 v s$ polluted $=5.20 \pm 0.09 \mathrm{~g} / \mathrm{g}, \mathrm{P}=0.688$; intermittent short-term - total $20 \mathrm{~h}$ : control = $4.86 \pm 0.13 v s$ polluted $=5.20 \pm 0.18 \mathrm{~g} / \mathrm{g}, \mathrm{P}$ $=0.167)$.

\section{Discussion}

In the present study, rats were exposed to vehicle polluted (urban) or clean (filtered) ambient air on a short-term basis. Their lungs were evaluated for lipid damage and showed a time-dependent increase of lipid peroxidation. Rats exposed to particulate matter for $20 \mathrm{~h}$ presented an almost 2-fold higher lipid peroxidation when compared to rats exposed for $6 \mathrm{~h}$. Our results agree with previous studies with animals breathing CAPs for $5 \mathrm{~h}$, which presented an increase in oxidant levels in the lung and heart $(14,19)$. Both observations would be compatible with Fentontype reactions catalyzed by transition metals, redox-cycling processes, or biochemical changes triggered by non-covalent binding to membrane receptors. It is also important to point out that particulate matter concentrations in studies using the CAP model were $300-400 \mu \mathrm{g} / \mathrm{m}^{3}$ (total mass - on average) while in our study they were $110-140 \mu \mathrm{g} / \mathrm{m}^{3}$. In addition, our findings showed that even a lower concentration of particulate matter, considered safe, was able to promote damage to membrane lipid in the lung.

Pro-inflammatory and toxic effects of particulate matter have been reproduced in the laboratory in studies on humans (22), on animal models $(23,24)$ and on cells in culture (25). Pulmonary oxidative stress is related to polymorphonuclear neutrophil (PMN) count in BAL and to PMN infiltration (26-29), and these biological effects were prevented by $\mathrm{N}$-acetylcysteine treat- ment (15). We observed that rats exposed to ambient vehicular pollution for $20 \mathrm{~h}$ in Porto Alegre showed a significant accumulation of PMN leukocytes in BAL (Figure 2B), a fact that was not detected in rats submitted to $6 \mathrm{~h}$ of exposure (Figure 2A). PMN influx was not accompanied by significant changes in total protein levels, in agreement with the findings of Rhoden et al. (15). Particulate matter-induced oxidative stress is associ-
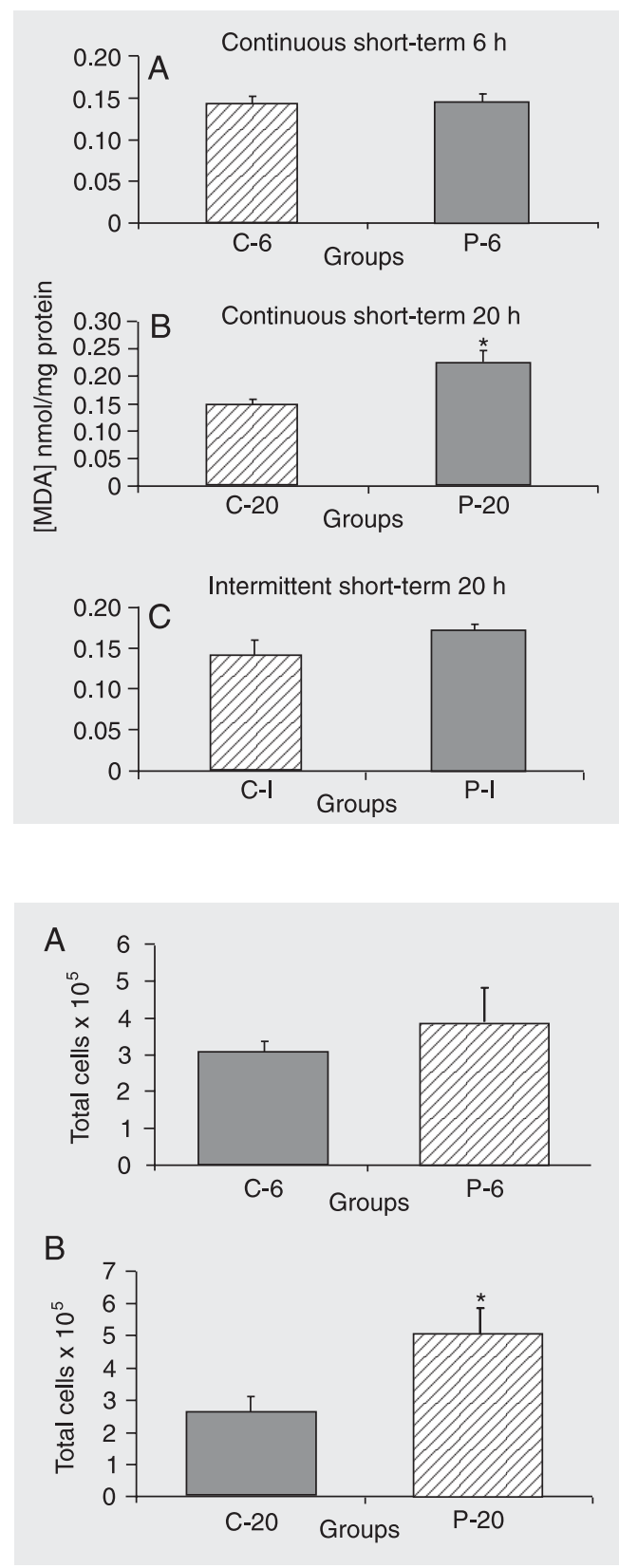

Figure 1. Effect of ambient particulate air pollution from vehicles on rat lung lipid peroxidation. Data are reported as the mean \pm SEM of 4-8 independent determinations. $A$, Continuous short-term - 6 h (C-6, P-6); $P=0.950 . B$, Continuous shortterm - 20 h (C-20, P-20); *P = 0.040 compared to control (unpaired Student $t$-test). $C$, Intermittent short-term - total $20 \mathrm{~h}$ $(\mathrm{C}-\mathrm{I}, \mathrm{P}-\mathrm{I}) ; \mathrm{P}=0.272$. MDA = malondialdehyde.

Figure 2. Effect of ambient particulate air pollution from vehicles on rat total cell number in bronchoalveolar lavage. Data are reported as the mean \pm SEM of 5-6 independent determinations. $A$, Continuous shortterm - 6 h (C-6, P6); $\mathrm{P}=0.195$. $B$, Continuous short-term $-20 \mathrm{~h}$ (C-20, P-20); ${ }^{*} \mathrm{P}=0.041 \mathrm{com}$ pared to control (unpaired Student $t$-test). 
ated with the development of lung inflammation and tissue damage $(27,30,31)$. However, the wet/dry ratio, a measurement of global tissue damage, did not show a significant increase as a function of exposure time in the present study, in contrast to results reported by other investigators that showed significant development of lung edema in animals exposed to CAPs for $5 \mathrm{~h}$ (14). One limitation of the present study was that we did not determine the composition of particulate matter. Particularly important in this respect is the fact that experimental studies with CAPs have been performed with higher doses of particulate matter, resulting in different levels of lung inflammatory effects. However, our experimental design had the advantage of reproducing the real concentration of particulate matter for which effects have been detected in epidemiological studies (1-9) and the results observed offer important evidence regarding inflammation and the oxidant effects of particulate matter at sites with acceptable pollution indexes.

The experimental model employed in this study indicates that combining animal studies with "real world exposures" may be of use to understand the pathogenesis of lung injury promoted by urban particles, as well as to devise strategies of pollution control for the minimization of health effects.

\section{Acknowledgments}

Special thanks are due to the staff of Laboratory of Experimental Air Pollution of the Medical School, University of São Paulo, São Paulo, SP, Brazil, for technical assistance. We also thank the Porto Alegre Ambient Protection State Foundation (FEPAM) for the atmospheric data.

\section{References}

1. Dockery DW, Pope CA III, Xu X, Spengler JD, Ware JH, Fay ME, et al. An association between air pollution and mortality in six U.S. cities. N Engl J Med 1993; 329: 1753-1759.

2. Saldiva PH, Lichtenfels AJ, Paiva PS, Barone IA, Martins MA, Massad E, et al. Association between air pollution and mortality due to respiratory diseases in children in São Paulo, Brazil: a preliminary report. Environ Res 1994; 65: 218-225.

3. Saldiva PH, Pope CA III, Schwartz J, Dockery DW, Lichtenfels AJ, Salge JM, et al. Air pollution and mortality in elderly people: a timeseries study in São Paulo, Brazil. Arch Environ Health 1995; 50: 159-163.

4. Dockery DW. Epidemiologic evidence of cardiovascular effects of particulate air pollution. Environ Health Perspect 2001; 109 (Suppl 4): 483-486.

5. Schwartz J, Slater D, Larson TV, Pierson WE, Koenig JQ. Particulate air pollution and hospital emergency room visits for asthma in Seattle. Am Rev Respir Dis 1993; 147: 826-831.

6. Schwartz J. Air pollution and blood markers of cardiovascular risk. Environ Health Perspect 2001; 109 (Suppl 3): 405-409.

7. Donaldson K, Stone V, Seaton A, MacNee W. Ambient particle inhalation and the cardiovascular system: potential mechanisms. Environ Health Perspect 2001; 109 (Suppl 4): 523-527.

8. Zareba W, Nomura A, Couderc JP. Cardiovascular effects of air pollution: what to measure in ECG? Environ Health Perspect 2001; 109 (Suppl 4): 533-538.

9. Pope CA III. Epidemiology of fine particulate air pollution and human health: biologic mechanisms and who's at risk? Environ Health Perspect 2000; 108 (Suppl 4): 713-723.
10. Braga AL, Saldiva PH, Pereira LA, Menezes JJ, Conceicao GM, Lin $\mathrm{CA}$, et al. Health effects of air pollution exposure on children and adolescents in São Paulo, Brazil. Pediatr Pulmonol 2001; 31: 106113.

11. Farhat SC, Paulo RL, Shimoda TM, Conceicao GM, Lin CA, Braga $A L$, et al. Effect of air pollution on pediatric respiratory emergency room visits and hospital admissions. Braz J Med Biol Res 2005; 38 : 227-235.

12. Kaiser R, Romieu I, Medina S, Schwartz J, Krzyzanowski M, Kunzli N. Air pollution attributable postneonatal infant mortality in U.S. metropolitan areas: a risk assessment study. Environ Health 2004; 3: 4 .

13. Stringer B, Kobzik L. Environmental particulate-mediated cytokine production in lung epithelial cells (A549): role of preexisting inflammation and oxidant stress. J Toxicol Environ Health A 1998; 55: 3144.

14. Gurgueira SA, Lawrence J, Coull B, Murthy GGK, Gonzalez-Flecha B. Rapid increases in the steady-state concentration of reactive oxygen species in the lungs and heart after particulate air pollution inhalation. Environ Health Perspect 2002; 110: 749-755.

15. Rhoden CR, Lawrence J, Godleski JJ, Gonzalez-Flecha B. N-acetylcysteine prevents lung inflammation after short-term inhalation exposure to concentrated ambient particles. Toxicol Sci 2004; 79: 296-303.

16. Banco Nacional de Desenvolvimento Econômico e Social - BNDES. Mobilidade urbana em regiões metropolitanas. Ministério das Cidades, Porto Alegre. http://www.bndes.gov.br/conhecimento/ seminario/cidade_20a.pdf. Accessed July 29, 2005. 
17. Massad E, Saldiva CD, Cardoso LM, da Silva R, Saldiva PH, Bohm GM. Acute toxicity of gasoline and ethanol automobile engine exhaust gases. Toxicol Lett 1985; 26: 187-192.

18. Saldiva $\mathrm{PH}$. Air pollution in urban areas: the role of automotive emissions as a public health problem. Int J Tuberc Lung Dis 1998; 2: 868.

19. Rhoden CR, Wellenius GA, Ghelfi E, Lawrence J, Gonzalez-Flecha B. PM-induced cardiac oxidative stress and dysfunction are mediated by autonomic stimulation. Biochim Biophys Acta 2005; 1725: 305-313.

20. Buege JA, Aust SD. Microsomal lipid peroxidation. Methods Enzymol 1978; 52: 302-310.

21. Schleicher $\mathrm{E}$, Wieland $\mathrm{OH}$. Evaluation of the Bradford method for protein determination in body fluids. J Clin Chem Clin Biochem 1978; 16: 533-534.

22. Ghio AJ, Kim C, Devlin RB. Concentrated ambient air particles induce mild pulmonary inflammation in healthy human volunteers. Am J Respir Crit Care Med 2000; 162: 981-988.

23. Clarke RW, Catalano PJ, Coull B, Koutrakis P, Murthy GGK, Rice T, et al. Age-related responses in rats to concentrated urban air particles (CAPs). Inhal Toxicol 2000; 12 (Suppl 1): 73-84.

24. Clarke RW, Coull B, Reinisch U, Catalano P, Killingsworth CR, Koutrakis $\mathrm{P}$, et al. Inhaled concentrated ambient particles are associated with hematologic and bronchoalveolar lavage changes in canines. Environ Health Perspect 2000; 108: 1179-1187.
25. Dagher Z, Garcon G, Gosset P, Ledoux F, Surpateanu G, Courcot $D$, et al. Pro-inflammatory effects of Dunkerque city air pollution particulate matter 2.5 in human epithelial lung cells (L132) in culture. J Appl Toxicol 2005; 25: 166-175.

26. Ferin J, Oberdorster G, Penney DP. Pulmonary retention of ultrafine and fine particles in rats. Am J Respir Cell Mol Biol 1992; 6: 535-542.

27. Kennedy T, Ghio AJ, Reed W, Samet J, Zagorski J, Quay J, et al. Copper-dependent inflammation and nuclear factor-kappaB activation by particulate air pollution. Am J Respir Cell Mol Biol 1998; 19 : 366-378.

28. Li XY, Gilmour PS, Donaldson K, MacNee W. Free radical activity and pro-inflammatory effects of particulate air pollution (PM10) in vivo and in vitro. Thorax 1996; 51: 1216-1222.

29. Li XY, Gilmour PS, Donaldson K, MacNee W. In vivo and in vitro proinflammatory effects of particulate air pollution (PM10). Environ Health Perspect 1997; 105 (Suppl 5): 1279-1283.

30. Shukla A, Timblin C, BeruBe K, Gordon T, McKinney W, Driscoll K, et al. Inhaled particulate matter causes expression of nuclear factor (NF)-kappaB-related genes and oxidant-dependent NF-kappaB activation in vitro. Am J Respir Cell Mol Biol 2000; 23: 182-187.

31. Jimenez LA, Thompson J, Brown DA, Rahman I, Antonicelli F, Duffin R, et al. Activation of NF-kappaB by $\mathrm{PM}(10)$ occurs via an iron-mediated mechanism in the absence of IkappaB degradation. Toxicol Appl Pharmacol 2000; 166: 101-110. 